\title{
PENINGKATAN KEUNGGULAN PRODUK MELALUI PENYULUHAN STRATEGI PEMASARAN PRODUK UMKM DESA KADUBEREUM KECAMATAN PABUARAN, KABUPATEN SERANG
}

\author{
Nugrahini Kusumawati ${ }^{1}$, Surti Zahra ${ }^{2}$ \\ 1Jurusan Akuntansi Universitas Bina Bangsa \\ 2 Jurusan Manajemen Universitas Bina Bangsa \\ Email: 1innanugrahini@gmail.com, 22zahra3803@gmail.com
}

\begin{abstract}
Abstrak
Masyarakat desa Kadubeureum kecamatan Pabuaran, beberapa ibu rumah tangga untuk meningkatkan ekonomi keluarganya melakukan kegiatan wirausaha. Terdapat kegiatan wirausaha yang berbagai macam tergantung pada keahlian / kemampuan dari masingmasing individu. Permasalah yang dihadapi adalah pemasaran produk yang mereka hasilkan dijual ke pasar induk yang jaraknya cukup jauh dari desa Kadubeureun, kurangnya pengetahuan masyarakat tentang pengemasan, dan kurangnya inovasi masyarakat dalam membuat produk. Untuk membantu UMKM dalam memberi solusi maka metode pelaksanaan yang digunakan setelah dilakukan survey maka memberikan penyuluhan mengenai strategi pemasaran dan pelatihan pengembangan produk. Hasilnya adalah menambah wawasan dan pengetahuan masyarakat tentang strategi pemasaran dan pengembangan produk.
\end{abstract}

Kata kunci : Peningkatan keunggulan produk, Penyuluhan, Strategi pemasaran

\begin{abstract}
The people of Kadubeureum village pabuaran sub-district, some housewives to improve their family's economy doing entrepreneurial activities. There are various entrepreneurial activities depending on the skills /abilities of each individual. The problems faced are the marketing of products they produce sold to the parent market which is quite far from kadubeureun village, lack of public knowledge about packaging, and lack of community innovation in making products. To assist UMKM in providing solutions then the implementation methods used after the survey, then provide counseling on marketing strategies and product development training. The result is to add insight and public knowledge about marketing strategies and product development.
\end{abstract}

Keywords: Enhanced product excellence, counseling, marketing strategies 


\section{PENDAHULUAN}

Upaya meningkatkan ketahanan keluarga tentu saja dengan upaya peningkatan sumber ekonomi bagi keluarga untuk kehidupan sehari-hari, salah satunya yang dilakukan suatu keluarga yang tidak memiliki penghasilan tetap atau bagi keluarga yang memiliki penghasilan yang tidak mencukupi untuk kebutuhan sehari-hari , dimana dalam suatu keluarga akan menambah penghasilan supaya kebutuhan sehari-harinya tercukupi dengan melakukan wirausaha.(Pengembangan et al., n.d.) Usaha rumah tangga di Indonesia memiliki peranan penting dalam menyerap tenaga kerja, peningkatan jumlah unit usaha dan menambah pendapatan keluarga. (Werdani et al., 2020). Kewirausahaan adalah kemampuan kreatif dan inovatif yang dijadikan dasar, kiat, dan sumber daya untuk peluang menuju sukses.(Gentari et al., 2019). Begitu juga yang dilakukan beberapa masyarakat desa Kadubeureum kecamatan Pabuaran, beberapa ibu rumah tangga untuk meningkatkan ekonomi keluarganya melakukan kegiatan wirausaha. Terdapat kegiatan wirausaha yang berbagai macam tergantung pada keahlian / kemampuan dari masing-masing individu. Manfaat bagi masyakat jika berwirausaha tentunya dapat meningkatkan pendapatan keluarga. (Arti, Tujuan Dan Manfaat Berwirausaha, n.d.) Maka kami tertarik untuk memberikan penyuluhan tentang strategi pemasaran guna membantu mereka untuk meringankan permasalah yang ada, diantaranya: (1) Pemasaran produk yang mereka hasilkan masih menggunakan pemasaran konvensional dengan menjualnya ke pasar induk yang jaraknya cukup jauh dari desa Kadubeureun, (2) Kurangnya pengetahuan masyarakat tentang pengemasan, (3) kurangnya inovasi masyarakat dalam membuat produk. Untuk memberikan solusi dari permasalahan di atas yaitu dengan memberikan penyuluhan kepada mereka mengenai strategi pemasaran agar produk menjadi unggul dalam persaingan, selanjutkan dilakukan pendampingan agar usaha yang mereka jalankan dapat berkembang sehingga kesuksesan bisa mereka raih.

Secara umum keadaan Desa Kadubeureum merupakan daerah dataran tinggi, dengan ketinggian 197 meter diatas permukaan laut. Desa Kadubeureum mempunyai iklim tropis sehingga mempunyai pengaruh langsung terhadap aktivitas pertanian dan pola tanam di desa ini. Sebagian besar penduduk Desa Kadubereum bekerja di sektor Pertanian Hal ini didukung oleh faktor iklim dan kondisi lahan pertanian yang luas yang terdiri dari persawahan dan perkebunan. 


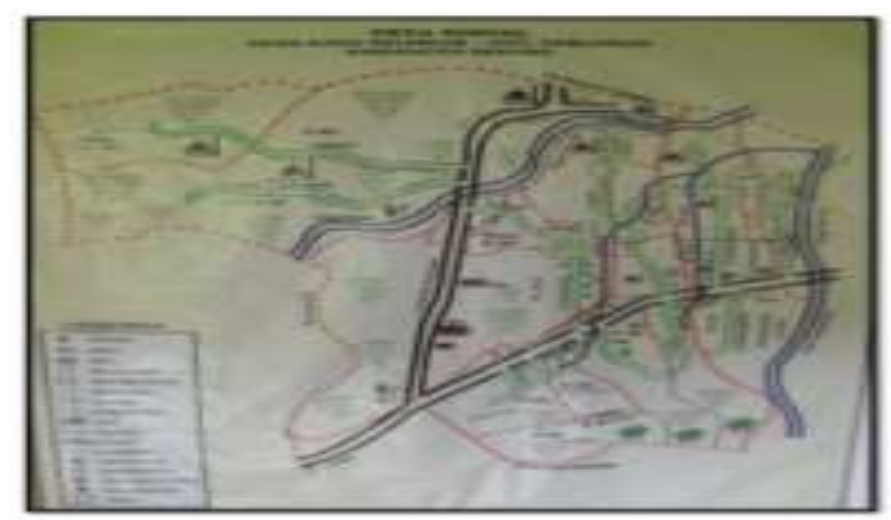

Gambar 1.1. Peta lokasi Desa

Kadubeureum Kec. Paabuaran Kab. Serang

Profil Desa

Desa Kadubeureum memiliki potensi di bidang pertanian, oleh sebab itu mayoritas penduduk bekerja sebagai buruh tani. Berikut data lengkapnya.

\begin{tabular}{|l|l|}
\hline Jenis pekerjaan & Jumlah \\
\hline Karyawan swasta & 100 orang \\
\hline PNS/TNI/POLRI & 35 orang \\
\hline Wiraswasta & 125 orang \\
\hline Pedagang & 5 orang \\
\hline Petani & 39 orang \\
\hline Buruh tani & 406 orang \\
\hline Pensiunan & 2 orang \\
\hline Nelayan & 0 orang \\
\hline
\end{tabular}

\section{METODE PELAKSANAAN}

Metode pelaksanaan yang dilakukan adalah melakukan survey kewirausahaan masyarakat desa Kadubereum, mengumpulkan data berapa banyak masyarakat yang memiliki usaha, kemudian memilah berapa banyak usaha yang memanfaatkan potensi alam. Selanjutnya dilakukan identifikasi masalah yang dihadapi oleh UMKM yang ada di desa tersebut. Dari hasil survey dan identifikasi masalah tersebut, maka tim pengabdian masyarakat menetapkan pendekatan solusi bagi UMKM tersebut dengan metode ceramah yaitu dengan memberikan penyuluhan tentang strategi pemasaran dan pelatihan pengembangan produk dengan mengajarkan inovasi serta pengemasan produk yang ada.

\section{HASIL KEGIATAN $\quad$ DAN PEMBAHASAN}

Setelah dilakukan survey dan identifikasi masalah, diperoleh beberapa hal yaitu potensi sumber daya alam yang ada di desa Kadubereum cukup banyak yaitu pisang, ubi, talas,singkong dan sukun. Potensi alam tersebut bisa dikembangkan untuk menjadi suatu produk sehingga bisa dijual dan menambah penghasilan bagi warga desa Kadubereum. Hanya saja di desa ini belum banyak masyarakat memanfaatkan potensi sumber daya alam ini untuk inovasi produk. Hanya sedikit masyarakat yang memanfaatkan sumber daya alam untuk inovasi produk . Masyarakat memahami bahwa pisang, ubi, talas, singkong hanya untuk direbus atau digoreng. Untuk dilakukan inovasi produk misalnya dijadikan kripik singkong, kripik pisang, kripik ubi belum banyak yang melakukan inovasi produk. Di desa Kadubereum terdapat beberapa saja yang mengolah pisang, singkong, ubi menjadi kripik. Namun hanya satu wirausaha saja yang sudah berkembang pesat dan merupakan keunggulan desa Kadubereum yaitu pengusaha berbagai macam kripik dengan berbagai rasa. Terdapat ada beberapa yang mengolah umbi-umbian tersebut menjadi kripik, namun hanya satu varian rasa yaitu rasa 
original. Jika dilihat potensi alam yang dimiliki desa Kadubereum dimana melimpahnya bahan baku seharusmya terdapat lebih banyak yang berwirausaha pengolahan kripik tersebut. Namun terdapat beberapa masalah dan kendala yang dihadapi terkait pengembangan potensi sumber alam desa. Kurangnya sumber daya manusia untuk pengolahan kripik tersebut karena mayoritas masyarakat memilih bekerja sebagai buruh tani. Keterbatasan sunber daya manusia ini berdampak pada banyaknya permintaan produk yang tidak dapat terpenuhi. Kendala yang dihadapi UMKM pengolahan kripik yaitu terbatasnya peralatan yang dimiliki dimana masih menggunakan alat seadanya. Memasarkan produk hanya sebatas di pasar induk yang jaraknya cukup jauh sehingga kesulitan dalam memasarkan produk dalam jumlah yang banyak.

Dari masalah yang dihadapi tersebut maka tim pengabdian masyarakat mengambil solusi dengan mengundang UMKM yang ada di desa Kadubereum, bekerjasama dengan pihak BUMDES memberikan penyuluhan strategi pemasaran dan pelatihan pengembangan produk dengan mengajarkan inovasi serta pengemasan produk yang ada, dengan pengemasan produk merupakan salah satu bagian dari strategi pemasaran.(Masitoh et al., 2019) Penyampaian materi yang mudah dipahami oleh masyarakat, pendekatan komunikasi menggunakan interaksi dengan tujuan UMKM yang mengikuti penyuluhan ini memperoleh manfaat dan mendapatkan solusi masalah tentang produk yang dihasilkan. Kurang lebih ada 50 peserta UMKM yang mengikuti penyuluhan ini, dan tim pengabdian masyarakat beserta BUMDES berinisiasi untuk membantu masyarakat dalam memasarkan produknya tidak hanya di pasar saja dengan jarak yang cukup jauh, namun juga dapat memasarkan produknya di sekitar desa Kadubereum, menginagat Desa Kadubereum berada di dekat jalan menuju tempat wisata pantai Anyer Carita dan tempat wisata lainnya.
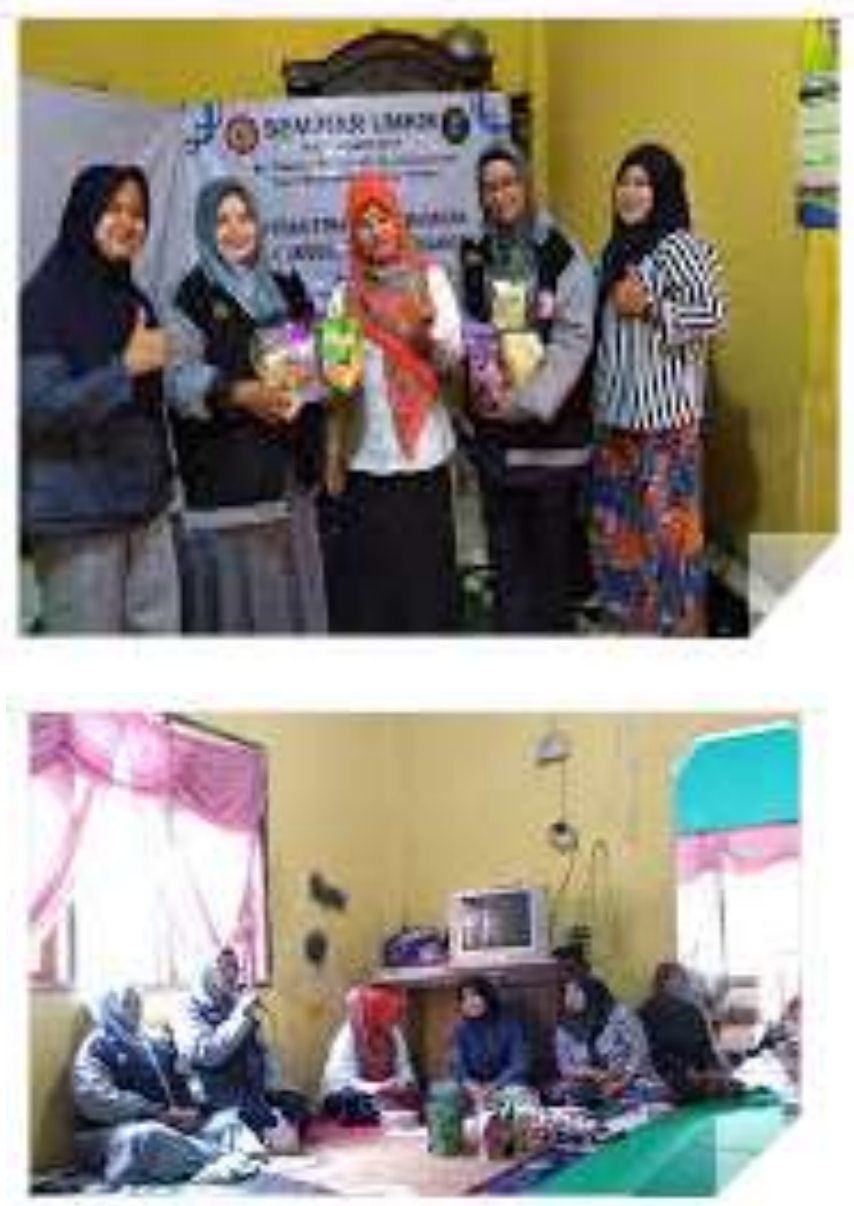


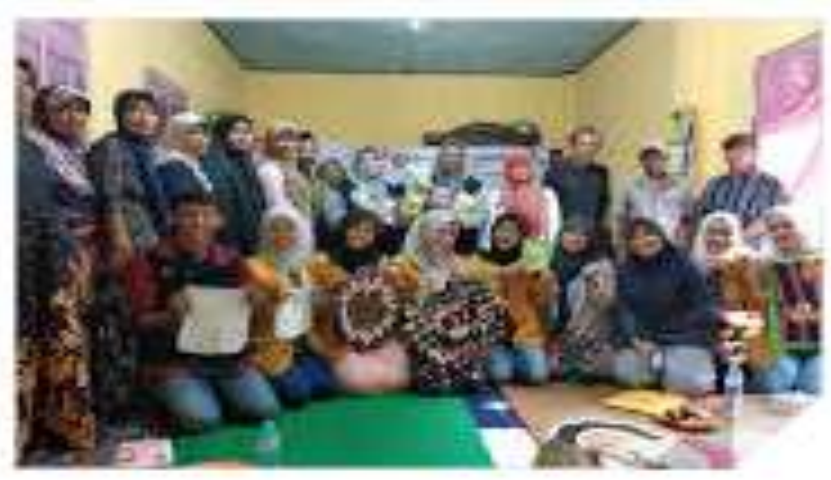

KESIMPULAN

Dengan adanya penyuluhan strategi pemasaran dan terlaksanaya pelatihan pengembangan produk dengan mengajarkan inovasi serta pengemasan produk bagi pelaku UMKM Desa Kadubeureum Kec. Pabuaran Kab. Serang telah menambah wawasan dan pengetahuan masyarakat terutama tentang strategi pemasaran dengan melakukan inovasi produk serta mengemas produk yang mereka produksi dengan kemasan yang menarik, dapat menggali potensi desa untuk menjadi ladang usaha masyarkat sekitar, dan dapat memasarkan produk yang mereka hasilkan di Desa Kadubeureum yang lokasinya bisa selalu dilewati oleh para pengunjung tempat wisata dari arah Anyar dan sebaliknya. Diharapkan kerja sama dari seluruh pemangku kekuasaan di desa tersebut untuk terus bisa memantau para pelaku UMKM sehingga mereka dapat menjadi UMKM yang siap berinovasi dan berdaya saing serta dapat mewujudkan ekonomi mandiri bagi masyarakat sekitar.
Arti, Tujuan dan Manfaat Berwirausaha. (n.d.).

https://www.kompasiana.com/did iy46.kompasiana.com/552b73316ea8 347f4e8b45a8/artitujuandanmanfaat-berwirausaha

Gentari, R. E., Dewi, L. M., \& Syamsudin, S. (2019). Peningkatan Kemandirian Perekonomian Melalui Program Wirausaha Sosial Dan Gotong Royong Desa Sambi Gerowong Kel Sukawana Kec Serang Provinsi Banten. Kaibon Abhinaya: Jurnal Pengabdian Masyarakat, 1(1), 7. https://doi.org/10.30656/ka.v1i1.9 75

Masitoh, M. R., Dewi, L. M., Sunaryo, D., \& Wibowo, H. A. (2019).

Peningkatan Kesejahteraan Melalui Penyuluhan Kewirausahaan pada Warga PKK di Dusun Nanggulan, Kabupaten Sleman. Kaibon Abhinaya: Jurnal Pengabdian Masyarakat, 1(1), 24. https://doi.org/10.30656/ka.v1i1.9 78

Pengembangan, B., Anak, P., \& Dini, U. (n.d.). i | Buku Seri Orang Tua: Penguatan Ketahanan Keluarga.

Werdani, R. E., Kurniawati, N. I., Sukoco, J. B., Windriya, A., \& Iskandar, D. (2020). Pelatihan Pemasaran Produk Homemade Melalui Sosial Media. JPPM (Jurnal Pengabdian Dan Pemberdayaan Masyarakat), 4(1), 1. https://doi.org/10.30595/jppm.v4i 1.4655

\section{REFERENSI}

